\title{
The influence of wild boar (Sus scrofa) on microhabitat quality for the endangered butterfly Pyrgus malvae in the Netherlands
}

\author{
Frédéric de Schaetzen ${ }^{1,4} \cdot$ Frank van Langevelde $^{1} \cdot$ Michiel F. WallisDeVries $^{2,3}$ (I)
}

Received: 25 June 2017 / Accepted: 28 November 2017 / Published online: 18 January 2018

(c) The Author(s) 2018. This article is an open access publication

\begin{abstract}
The decline of open habitats in Europe, such as semi-natural grasslands and heathlands, has caused a general decline in biodiversity, which has been well documented for butterflies. Current conservation practices often involve grazing by domestic livestock to maintain suitable butterfly habitats. The extent to which wild ungulates may play a similar role remains largely unknown. Through their rooting activity, wild boar could be effective to reduce grass encroachment and restore pioneer microhabitats that are vital to many grassland insects in temperate climates. Here, we assessed the microhabitat requirements of Pyrgus malvae, an endangered butterfly of heathland and grassland habitats in the Netherlands, with special attention for the influence of wild boar rooting. To date, oviposition site selection of this species has concentrated on calcareous grasslands, whereas we also include heathlands. Overall, larval occupancy was higher in warm, open and sparsely vegetated microhabitats, which supports earlier findings. In heathland, microhabitat occupancy was positively affected by bryophyte and litter cover. In heath-grassland mosaic, microhabitat occupancy was also influenced by bryophyte and litter cover, but in addition low grass cover increased occupancy by favouring host plants. In grassland, only low grass cover and host plant cover determined microhabitat quality. Across all habitats, occupied microhabitats were characterized by lower vegetation as well as higher average daytime temperatures than unoccupied microhabitats. We discovered that wild boar play an important role in reducing grass cover by shallow rooting in grass patches, thereby increasing host plant availability. Hence, wild boar may have an added value in maintaining and restoring $P$. malvae microhabitats in grassland habitats in addition to grazing by domestic livestock.
\end{abstract}

Keywords Conservation ecology $\cdot$ Ecosystem engineering $\cdot$ Herbivore impact $\cdot$ Heathland $\cdot$ Habitat quality $\cdot$ Butterflies

Michiel F. WallisDeVries

michiel.wallisdevries@ devlinderstichting.nl

1 Resource Ecology Group, Wageningen University, P.O. Box 47, 6700 AA Wageningen, The Netherlands

2 Plant Ecology and Nature Conservation Group, Wageningen University, P.O. Box 47, 6700 AA Wageningen, The Netherlands

3 De Vlinderstichting/Dutch Butterfly Conservation, P.O. Box 506, 6700 AM Wageningen, The Netherlands

4 Department of Civil, Environmental and Geomatic Engineering, ETH Zurich, Institute of Environmental Engineering, Stefano-Franscini-Platz 5, 8093 Zurich, Switzerland

\section{Introduction}

The shift from traditional agricultural practices to agricultural intensification, afforestation, and abandonment of land are major drivers in the loss of open habitats, such as seminatural grasslands and heathlands (Bakker and Berendse 1999; Poschlod et al. 2005; Streitberger and Fartmann 2016). Semi-natural grasslands and heathlands are considered to be hotspots for biodiversity in Europe (Veen and Jefferson 2009) and are the preferred habitats for the majority of European butterfly species (Munguira et al. 2009; WallisDeVries and van Swaay 2009). As a result of habitat loss, population declines have been observed for almost a third of the butterfly species in Europe (van Swaay et al. 2010).

Appropriate habitat management of endangered butterfly species highly depends on sufficient knowledge of their required habitat quality parameters, which is often lacking (Schultz et al. 2008; Sutherland et al. 2004). Butterflies 
may require a variety of microhabitats to provide the vital resources required during subsequent life stages of their life cycle (Dennis et al. 2006; Wynhoff et al. 2008). In general, the larval stages constitute the longest part of the life cycle, during which mobility is limited. Therefore, specific larval habitat requirements should be met at a small spatial scale (Thomas 1991), such as the availability of specific host plant species (Munguira et al. 2009) and a sufficiently warm microclimate (Roy and Thomas 2003; Weiss et al. 1988). Consequently, effective microhabitat selection by females during oviposition strongly determines larval survival (García-Barros and Fartmann 2009). Elucidating the favourable conditions for larval development of threatened species thus may provide new insights for suitable habitat restoration and management (WallisDeVries et al. 2016).

In order to maintain biodiversity of open habitats, ecosystem engineers, such as large ungulates, are frequently used in conservation efforts (WallisDeVries 1998). Ecosystem engineers can destroy, create, modify and maintain habitats (Jones et al. 1994; Boogert et al. 2006; Byers et al. 2006). In Europe, the assemblage of large ungulates mainly consists of domestic livestock, i.e. cattle, sheep, goats and ponies. Positive impacts of grazing on butterfly and other arthropod communities are mainly achieved when stocking densities of large ungulates are low (van Klink et al. 2015; WallisDeVries and Raemakers 2001). However, maintaining the microhabitats of early successional species may require higher grazing intensity, which may be detrimental to late successional species depending on taller vegetation (WallisDeVries et al. 2016). Rotational or shepherded grazing may generate a potentially optimal mosaic of different grazing intensities in space and time (WallisDeVries et al. 2016; Enri et al. 2017), but also may result in additional management costs. An alternative option to achieve heterogeneity with suitable microhabitat could be to seek the benefit of wild ecosystem engineers that generate local disturbances. These might offer an added value in habitat management. Documented examples are still rare, but have been found in the abandoned pond meadows created by beaver (Castor canadensis) benefiting the butterfly Neonympha mitchellii francisci (Bartel et al. 2010), ant mounds from Lasius flavus favouring the butterfly Hesperia comma (Streitberger and Fartmann 2016), and mounds created by mole (Talpa europaea) that offer suitable microhabitat for the butterfly Pyrgus malvae (Streitberger and Fartmann 2013).

Another widespread ecosystem engineer is the wild boar (Sus scrofa) (Barrios-Garcia and Ballari 2012). S. scrofa overturns vegetation and disturbs the soil in search for belowground plant parts, fungi and invertebrates (Baubet et al. 2003; Sandom et al. 2013b), and thus has a distinctive impact on plant communities by setting back succession (Burrascano et al. 2015; Sandom et al. 2013a; Sims et al. 2014) with likely impacts on invertebrate communities
(Carpio et al. 2014). However, to date no detailed research was performed on the significance of soil disturbance by $S$. scrofa rooting on butterfly microhabitats.

Here, we studied the grizzled skipper (P. malvae L.) (Lepidoptera: Hesperiidae), which has seen declining populations resulting in a threatened status in North-West Europe (Brereton 1997; Krämer et al. 2012; Maes and Van Dyck 2001; Bos et al. 2006) although it still appears to be stable elsewhere in Europe (Van Swaay et al. 2010). Information on the microhabitat requirements of $P$. malvae was predominantly collected in calcareous grassland habitats of Great Britain (Brereton 1997) and central Germany (Krämer et al. 2012; Streitberger and Fartmann 2013) and in calcareous coastal dunes of the Netherlands (WallisDeVries 2010). In general, P. malvae prefers host plants in open vegetation, with patches of bare soil, rocks or litter that induce a warmer microclimate (Brereton 1997; Krämer et al. 2012; WallisDeVries 2010). Besides calcareous grasslands, P. malvae also may occur as a characteristic species on heathlands (Brereton 1997), for which information on larval microhabitat characteristics has been lacking to date. Therefore, this study aimed to assess both the larval microhabitat characteristics of $P$. malvae and the influence of $S$. scrofa rooting in creating these microhabitats. We hypothesized that, in view of existing knowledge on habitat preference, (1) $P$. malvae prefers warm, open microhabitats and that (2) wild boar rooting positively affects larval microhabitats by creating bare patches in established vegetation. These hypotheses were addressed in a field study on heathland and acid grassland in National Park De Hoge Veluwe in the Netherlands.

\section{Materials and methods}

\section{Study species}

Pyrgus malvae can be found throughout the Palearctic region from the Iberian Peninsula to East Asia and as far north as the middle of Scandinavia. In the Netherlands, P. malvae habitats range from wet to dry low-productive grasslands, coastal dunes and heathlands. It hibernates during the pupal stage and has an early flight period, starting at the end of April until early June, mostly in a single generation per year; in contrast to climatically warmer regions, a second generation is exceptional and only partial (Bos et al. 2006). P. malvae has a broad range of host plants within the Rosaceae family (Brereton 1997; Krämer et al. 2012), although it mostly uses Rubus caesius in coastal dunes and Potentilla erecta elsewhere in the Netherlands (Bos et al. 2006). In general, single eggs are laid on host plants and $P$. malvae caterpillars spin leaves together to form tents which 
provide them with a buffered microclimate and protection against predation (Brereton 1997).

\section{Study area}

The Dutch National Park de Hoge Veluwe $\left(52^{\circ} 4^{\prime} 43^{\prime \prime} \mathrm{N} / 5^{\circ} 49^{\prime} 56^{\prime \prime} \mathrm{E}\right)$ covers $54 \mathrm{~km}^{2}$ and is situated in the province of Gelderland, in the east of the Netherlands. The annual average temperature is $9.7^{\circ} \mathrm{C}$, with an average maximum temperature of $13.8^{\circ} \mathrm{C}$ and an average minimum temperature of $5.5^{\circ} \mathrm{C}$. The Veluwe has an annual precipitation ranging between 850 and $975 \mathrm{~mm}$ (ter Maat et al. 2013). The landscape is characterized by woodlands, heathlands, moorland pools and drift-sand and has been identified as an important biodiversity hotspot in the Natura 2000 Veluwe area (Zollinger et al. 2008). The area harbours ungulate populations (summer counts) of 300 red deer (Cervus elaphus), 160 roe deer (Capreolus capreolus), 270 mouflon (Ovis musimon) and 250 wild boar (S. scrofa). These population levels are maintained by a hunting policy from the Park management. Furthermore, domestic livestock has been absent from most of the Park, including the studied plots, since more than a century.

\section{Study design}

In July 2016, three plots, each covering 0.25 ha, were selected as suitable habitat for caterpillars of P. malvae, based on confirmed prior sightings of $P$. malvae and the presence of suitable Potentilla host plants. The selected plots reflected a distinct gradient in vegetation structure from heathland, with a high dwarf-shrub cover, to acid grassland, without dwarf-shrub cover (Table 1). Because of the obvious rooting activity of wild boar, we took special care to quantify their impact on larval microhabitats.

Data were collected in a paired design with 17-19 pairs per plot. For each occupied host plant, the nearest unoccupied host plant of the same species, was selected in a random direction, generated by a random direction generator on an android smartphone (Spinner App by TezSoft). If any traces of $P$. malvae activity on the nearest host plant were found, the next nearest host plant was selected.

In a radius of $25 \mathrm{~cm}$ around each occupied and unoccupied host plant sites, we recorded three types of microhabitat characteristics. First, proportional data on vegetation cover were recorded as the horizontal cover (\%) of wild boar rooting (WBR) activity and the cover of dwarf shrubs, host plants, herbs, grasses, bare soil and mosses/litter. As in earlier studies (Welander 2000; Burrascano et al. 2015; Sandom et al. 2013b; Sims et al. 2014), WBR activity was readily distinguished as large disturbed patches $\left(>1 \mathrm{~m}^{2}\right)$ with a lower microtopography, similar to sod cutting. These patches were created in the years prior to this study and were already recolonized by vegetation. WBR behaviour is rarely observed during the summer season (Welander 2000; Sims et al. 2014) and was not observed on or near any of the occupied or unoccupied host plants during the duration of this study. Mosses and litter were recorded as a combined variable as they provide a similar microclimate (WallisDeVries 2006) and shelter properties for larvae and pupae of P. malvae (Brereton 1997; Krämer et al. 2012).

Second, vegetation height $(\mathrm{cm})$ was recorded nine times per host plant site; for each of eight wind-direction axes plus a central measurement. The height of the host plant itself was also measured. All vegetation height measurements were carried out using the drop disk method (Holmes 1974), with a $10 \mathrm{~cm}$ diameter Styrofoam disk. VH_AVG (excluding host plant height) was calculated for both occupied and unoccupied host plant sites.

Third, temperature data were collected between July 23rd and August 26th with recording intervals of 5 min using Lascar EL-USB-2 data loggers (Lascar electronics UK). A data logger was placed south of each host plant with only the top remaining above-ground. For each host plant, one day cycle (10.00-16.00 h), based on maximum sunshine hour days and the following night cycle $(23.00-5.00 \mathrm{~h})$ was selected to calculate the average day and night temperature; warmer microclimatic conditions at occupied host plants were only

Table 1 Description of vegetation types based on overall dwarf-shrub cover, VH_AVG and characteristic plant species. The values were obtained from ten randomly located $1 \times 1 \mathrm{~m}^{2}$ plots within each habitat plot (unpubl. data)

\begin{tabular}{|c|c|c|c|c|}
\hline Vegetation type & $\begin{array}{l}\text { Dwarf- } \\
\text { shrub } \\
\text { cover }(\%)\end{array}$ & $\begin{array}{l}\text { Average veg- } \\
\text { etation height } \\
(\mathrm{cm})\end{array}$ & GPS coordinates & Characteristic plant species \\
\hline Heathland $(\mathrm{H})$ & $61.2 \pm 5.5$ & $33.9 \pm 1.0$ & $52^{\circ} 03^{\prime} 57.4^{\prime \prime} \mathrm{N} 5^{\circ} 50^{\prime} 55.5^{\prime \prime} \mathrm{E}$ & $\begin{array}{l}\text { Calluna vulgaris, Festuca filiformis, Molinia caerulea, } P \text {. } \\
\text { erecta }\end{array}$ \\
\hline Heath/Grassland (M) & $20.0 \pm 5.2$ & $16.5 \pm 0.9$ & $52^{\circ} 03^{\prime} 32.5^{\prime \prime} \mathrm{N} 5^{\circ} 51^{\prime} 10.0^{\prime \prime} \mathrm{E}$ & $\begin{array}{l}\text { C. vulgaris, Erica tetralix, Deschampsia flexuosa, F. filiformis, } \\
\text { Potentilla anglica }\end{array}$ \\
\hline Grassland (G) & 0 & $18.6 \pm 0.7$ & $52^{\circ} 04^{\prime} 29.4^{\prime \prime N} 5^{\circ} 51^{\prime} 51.6^{\prime \prime E}$ & $\begin{array}{l}\text { Agrostis capillaris, Agrostis vinealis, F. filiformis, Hypocha- } \\
\text { eris radicata, Jacobaea vulgaris, } P . \text { anglica }\end{array}$ \\
\hline
\end{tabular}

Mean \pm standard error 
expected because of solar heat during the day. Hourly sunshine data were retrieved from the nearest weather station in Deelen $\left(52^{\circ} 04^{\prime} \mathrm{N} / 05^{\circ} 53^{\prime} \mathrm{E}\right)$ to select data from sunny days (http://www.knmi.nl). Due to a limited number of data loggers, temperature measurements were collected for 36 host plant pairs (12 pairs per plot), while the proportional cover data and vegetation height data were measured for 53 host plant pairs (17 pairs for heathland and heath/grassland and 19 pairs for grassland).

\section{Statistical analysis}

First, an ordination analysis was carried out, in order to explore the distribution of host plants in relation to the recorded environmental variables. Subsequently, each environmental variable was analysed individually, using mixed models, to detect significant differences in host plant occupancy, vegetation type, and their interaction. Four highly correlated vegetation height variables (North East (NE), North West (NW), South East (SE) and South West (SW); Spearman correlation $r_{s}>0.6, p<0.001$ ) were excluded from further analyses.

After checking the lengths of gradient with a detrended canonical correspondence analysis (DCA; lengths of gradient $<3$ ), a redundancy analysis (RDA) was selected as the appropriate ordination method (Ter Braak and Smilauer 2002). Species data were represented in four classes: occupied and unoccupied host plants for each host plant species, $P$. erecta and P. anglica. The environmental data consisted of a selection of environmental variables in order to reduce the complexity of the interpretation (Fig. 1). Average day and night temperatures were excluded in the final model due to their low explanatory power. No data transformations were performed prior to the RDA.

Generalized linear (GLMMs) and linear mixed models (LMMs) were used to test for significant differences in environmental variables between occupied and unoccupied host plants, vegetation type and their interaction (as fixed effects). Random effects were host plant pair number and the date on which the respective host plant was measured. Host plant species was not included as a fixed or random effect, since it was highly correlated (Spearman correlation $r_{s}=0.748$, $\mathrm{p}<0.001$ ) with vegetation type. The proportional cover data were tested using a proportional binomial GLMM. Overdispersion effects were observed, due to many zero values in the proportional cover data. Therefore, an extra random effect was implemented with a unique value for each host plant. Moreover, a reduced dataset was used in case of dwarf-shrub cover (VS_DS) and WBR, since these variables were respectively not present in the grassland plot $(\mathrm{G})$ and the heathland plot $(\mathrm{H})$. Additionally, to further test the second hypothesis three proportional binomial GLMMs were

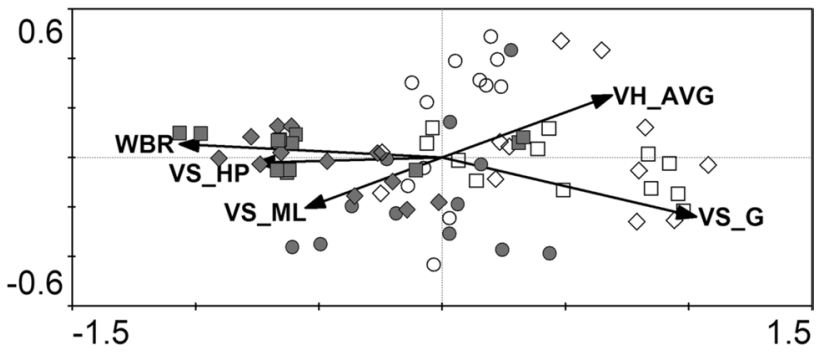

Fig. 1 RDA triplot including environmental variables. Host plants are represented by geometrical symbols for each vegetation type: circles $($ unfilled $)=$ heathland $(\mathrm{H})$; diamonds $($ unfilled $)=$ Heath/grassland $(\mathrm{M})$ and squares $(\leq)=$ grassland $(G)$. filled symbols represent occupied host plants, while open symbols are unoccupied host plants. Black arrows represent environmental variables: VH_AVG $=$ VH_AVG; $\mathrm{VS} \_\mathrm{G}=\%$ grass cover; VS_HP $=\%$ host plant cover; VS_ML $=\%$ cover of mosses/litter and $\mathrm{WBR}=\%$ cover rooted by wild boar. Three environmental variables, although included in the RDA, were omitted from the triplot due to low explanatory power: host plant height, herb cover and bare soil cover

performed to determine whether WBR influenced VS_G, VS_HP and mosses/litter cover (VS_ML). Vegetation height and temperature data were tested using LMMs. Normality of residuals was visually checked, using Q-Q plots, and if needed a square root transformation was performed.

GLMMs and LMMs were carried out in R, version 3.3.2 (R Core Team 2016) using the "Ime4" package (Bates et al. 2015), Tukey posthoc tests were calculated using the "multcomp" package (Hothorn et al. 2008). Moreover, the RDA was performed in Canoco 4.5 (Ter Braak and Smilauer 2002).

\section{Results}

In general, occupied host plants were found in open and sparsely vegetated habitats. The majority of the occupied plants were $P$. anglica (39 out of 53 occupied host plants). Occupied P. erecta host plants only occurred in the heathland plot $(\mathrm{H})$.

As we hypothesized, open and sparsely vegetated microhabitats, created by WBR, were used as larval microhabitats by $P$. malvae (Fig. 1). In total, $32.7 \%$ of the variation was explained by the selected environmental variables in the RDA. The first two ordination axes explained $32.4 \%$ of the total variation, $27.7 \%$ by the first axis and $4.7 \%$ by the second axis. There is a clear separation between occupied and unoccupied host plants along the first axis. Moreover, a separation between (1) heathland $(\mathrm{H})$ and (2) heath/grassland (M) and grassland (G) can be distinguished along both axes. WBR, VS_HP and VS_ML were positively correlated with the occupied host plants. Moreover, there was a clear correlation between WBR and VS_HP. In contrast, the average 
vegetation height (VH_AVG) and VS_G were negatively correlated with P. malvae microhabitat quality.

We found a significant interaction effect, between host plant occupancy and vegetation type, for VS_HP, VS_G, VS_ML and herb cover (Table 2). VS_HP differed between host plant pairs, with higher levels at occupied host plants, which increased from heathland to grassland (Fig. 2a). Similarly, the difference in VS_G between host plant pairs, with generally lower cover at occupied host plants, increased as well over vegetation type. However, VS_G decreased from heathland to grassland at occupied host plants, while increasing at unoccupied host plants. (Fig. 2b; Table 2). In contrast, mosses and litter cover were high at occupied host plants, yet sharply decreased going from heathland and heath/grassland to grassland. At unoccupied host plants, cover of mosses and litter was lower and gradually decreased from heathland to grassland (Fig. 2c; Table 2). Herb cover showed contrasts between host plant pairs and vegetation types. While higher values were recorded at occupied host plants in heathland and heath/grassland, herb cover was lower at unoccupied host plants in grassland. Moreover, VS_G was highest in heath/ grassland followed by grassland and heathland respectively (Fig. 2d; Table 2). No interaction effect was found for bare soil cover, dwarf-shrub cover and WBR. However, significant differences were found between vegetation types for dwarf-shrub cover, bare soil cover and WBR. Bare soil cover and WBR increased significantly from heathland to grassland (Fig. 2e, g; Table 2), with no WBR observed in the heathland habitat, while dwarf-shrub cover as expectantly decreased (Fig. 2f; Table 2). Moreover, WBR was significantly different for host plant occupancy, with higher values at occupied host plants (Fig. 2g; Table 2). In line with the second hypothesis, WBR had a significant positive impact on VS_HP (GLMM; Estimate $=1.55$; $\left.\mathrm{F}_{1,70}=34.80 ; \mathrm{P}<0.0001\right)$ and negative impact on VS_G $\left(\mathrm{GLMM}\right.$; Estimate $\left.=-1.43 ; \mathrm{F}_{1,70}=25.30 ; \mathrm{P}<0.0001\right)$. No significant relation was found between WBR and cover of mosses and litter.

No interaction effect was found for any of the vegetation height variables (Fig. 2; Table 2). All vegetation height variables, except the northern vegetation height, were significantly lower for occupied host plants (Fig. 2h-n; Table 2). Similarly, all vegetation height variables, except the western vegetation height, differed significantly between vegetation types, with generally taller vegetation in heathland and lower vegetation in heath/grassland and grassland. (Fig. $2 \mathrm{~g}-\mathrm{n}$; Table 2).

Finally, in line with the first hypothesis, the average daytime temperatures were significantly higher for occupied host plants, by $2.7 \pm 0.8^{\circ} \mathrm{C}$ on average maximum daytime temperature was higher by $3.2 \pm 0.8^{\circ} \mathrm{C}$. The significant

Table 2 Results of the linear and GLMMs testing for differences in the recorded environmental variables between the different levels of the interaction between host plant occupancy and vegetation type

\begin{tabular}{|c|c|c|c|c|c|c|c|c|c|c|c|c|c|}
\hline \multirow[t]{2}{*}{ Variable } & \multicolumn{5}{|c|}{ Host plant occupancy } & \multicolumn{4}{|c|}{ Vegetation type } & \multicolumn{4}{|c|}{ Occupancy $\times$ plot } \\
\hline & dir & $\mathrm{dfn}$ & dfd & $\mathrm{F}$ & $\mathrm{p}$ & $\mathrm{dfn}$ & dfd & $\mathrm{F}$ & $\mathrm{p}$ & $\mathrm{dfn}$ & dfd & $\mathrm{F}$ & $\mathrm{p}$ \\
\hline VS_HP (\%) & + & 1 & 104 & 30.543 & $<0.001$ & 2 & 103 & 81.496 & $<0.001$ & 2 & 103 & 5.753 & 0.004 \\
\hline VS_G (\%) & - & 1 & 104 & 15.598 & $<0.001$ & 2 & 103 & 3.973 & 0.022 & 2 & 103 & 6.301 & 0.003 \\
\hline VS_ML (\%) & + & 1 & 104 & 12.846 & $<0.001$ & 2 & 103 & 46.269 & $<0.001$ & 2 & 103 & 8.129 & $<0.001$ \\
\hline Herb cover $(\%)$ & $\mathrm{ns}$ & 1 & 104 & 0.004 & 0.949 & 2 & 103 & 43.447 & $<0.001$ & 2 & 103 & 3.273 & 0.042 \\
\hline Bare soil cover $(\%)$ & ns & 1 & 104 & 3.148 & 0.08 & 2 & 103 & 3.294 & 0.041 & 2 & 103 & 0.501 & 0.608 \\
\hline Dwarf-shrub cover $(\%)$ & ns & 1 & 66 & 3.594 & 0.062 & 1 & 66 & 43.863 & $<0.001$ & 1 & 66 & 0.108 & 0.744 \\
\hline WBR $(\%)$ & + & 1 & 70 & 14.973 & $<0.001$ & 1 & 70 & 6.706 & 0.012 & 1 & 70 & 0.836 & 0.364 \\
\hline North veg. height $(\mathrm{cm})$ & $\mathrm{ns}$ & 1 & 104 & 1.428 & 0.238 & 2 & 103 & 15.216 & $<\mathbf{0 . 0 0 1}$ & 2 & 103 & 0.993 & 0.378 \\
\hline East veg. height $(\mathrm{cm})$ & - & 1 & 104 & 27.067 & $<\mathbf{0 . 0 0 1}$ & 2 & 103 & 16.363 & $<0.001$ & 2 & 103 & 2.067 & 0.137 \\
\hline South veg. height $(\mathrm{cm})$ & - & 1 & 104 & 37.225 & $<0.001$ & 2 & 103 & 27.803 & $<0.001$ & 2 & 103 & 1.704 & 0.187 \\
\hline West veg. height $(\mathrm{cm})$ & - & 1 & 104 & 28.2 & $<0.001$ & 2 & 103 & 8.902 & 0.083 & 2 & 103 & 0.106 & 0.900 \\
\hline Central veg. height $(\mathrm{cm})$ & - & 1 & 104 & 51.39 & $<0.001$ & 2 & 103 & 11.022 & $<0.001$ & 2 & 103 & 0.103 & 0.902 \\
\hline Host plant height $(\mathrm{cm})$ & - & 1 & 104 & 20.748 & $<0.001$ & 2 & 103 & 11.42 & 0.007 & 2 & 103 & 0.176 & 0.839 \\
\hline Average veg. height $(\mathrm{cm})$ & - & 1 & 104 & 48.294 & $<0.001$ & 2 & 103 & 46.771 & $<0.001$ & 2 & 103 & 1.786 & 0.178 \\
\hline Average day temp. $\left({ }^{\circ} \mathrm{C}\right)$ & + & 1 & 70 & 10.108 & 0.003 & 2 & 69 & 3.873 & $\mathbf{0 . 0 3 1}$ & 2 & 69 & 0.191 & 0.827 \\
\hline Average night temp. $\left({ }^{\circ} \mathrm{C}\right)$ & $\mathrm{ns}$ & 1 & 70 & 1.021 & 0.32 & 2 & 69 & 0.094 & 0.911 & 2 & 69 & 2.919 & 0.068 \\
\hline
\end{tabular}

See Fig. 2 for mean values at occupied or vacant host pants in the different vegetation types. dir=indicates whether the estimates of host plant occupancy were positive, negative or not significant (ns)

Significant effects are indicated in bold

$d f n$ degrees of freedom numerator, $d f d$ degrees of freedom denominator 


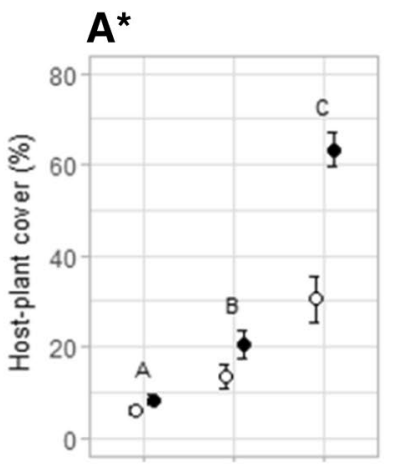

$E^{*}$
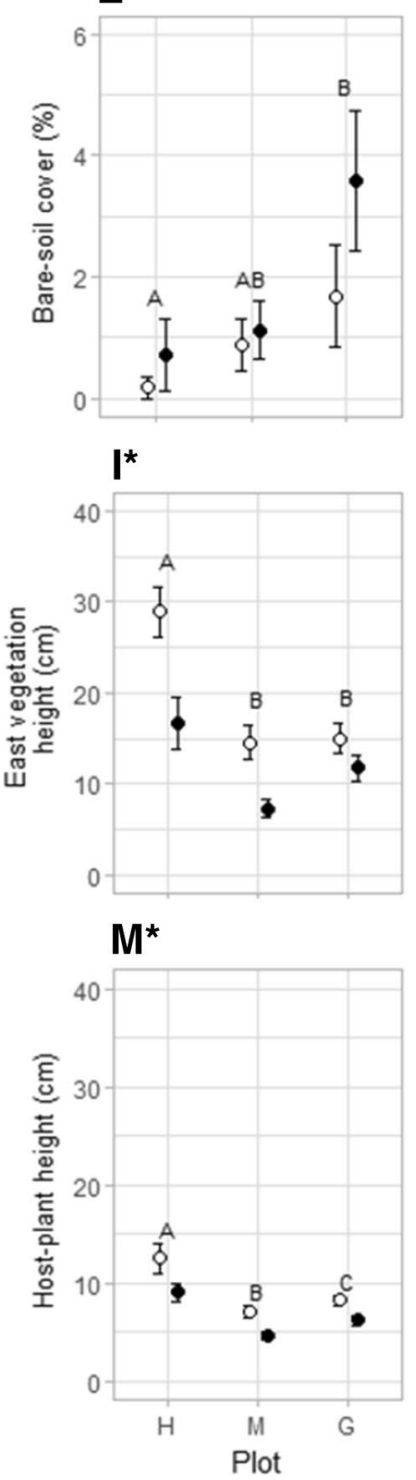
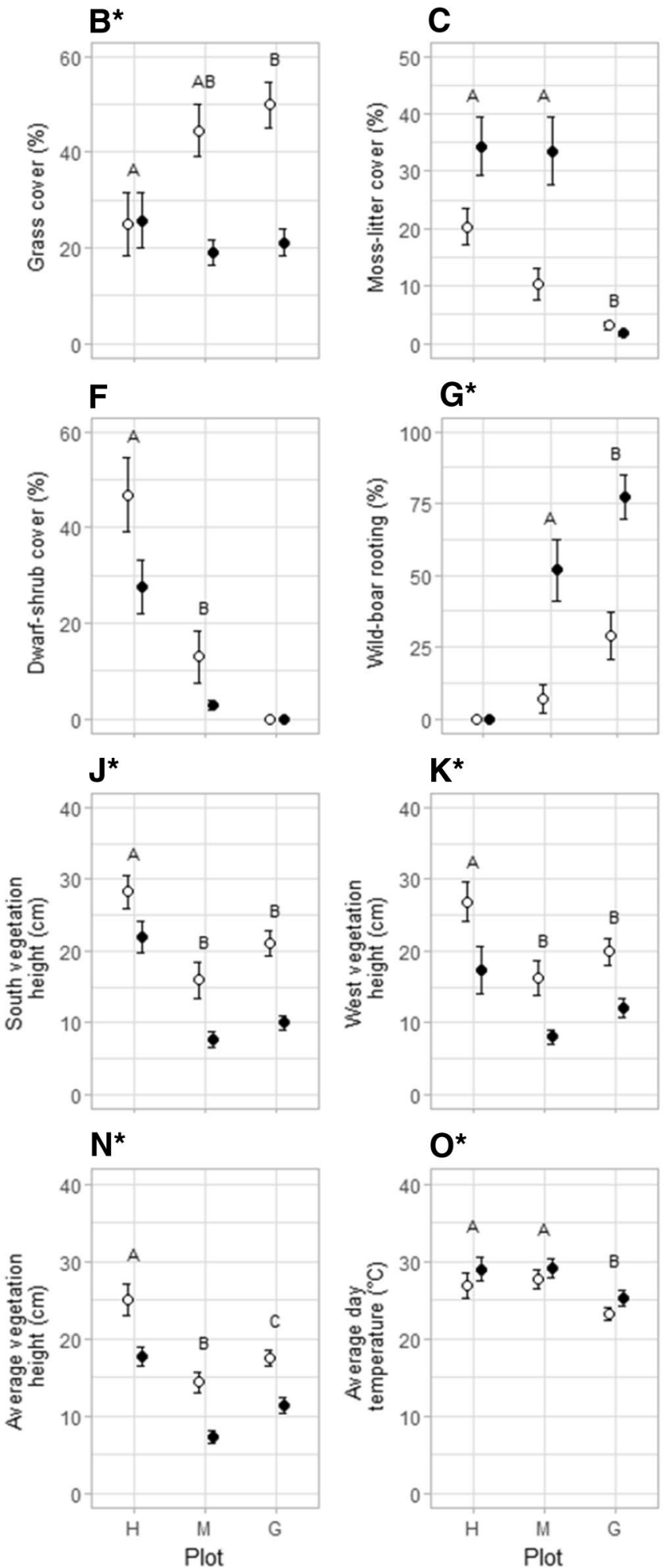

Fig. 2 Mean values of all environmental variables tested in mixed models for the different vegetation types at occupied and unoccupied host plants: a Dwarf-shrub cover (\%), b VS_HP (\%), c Herb cover (\%), d VS_G (\%), e Bare soil cover (\%), f Moss and litter cover (\%), g WBR cover $(\%) \mathbf{h}$ North vegetation height $(\mathrm{cm})$, i East vegetation height $(\mathrm{cm}), \mathbf{j}$ South vegetation height $(\mathrm{cm}), \mathbf{k}$ West vegetation height $(\mathrm{cm}), \mathbf{l}$ Central vegetation height $(\mathrm{cm}), \mathbf{m}$ Host plant height $(\mathrm{cm}), \mathbf{n}$ VH_AVG $(\mathrm{cm})$, o Average day temperature $\left({ }^{\circ} \mathrm{C}\right)$, p Average night
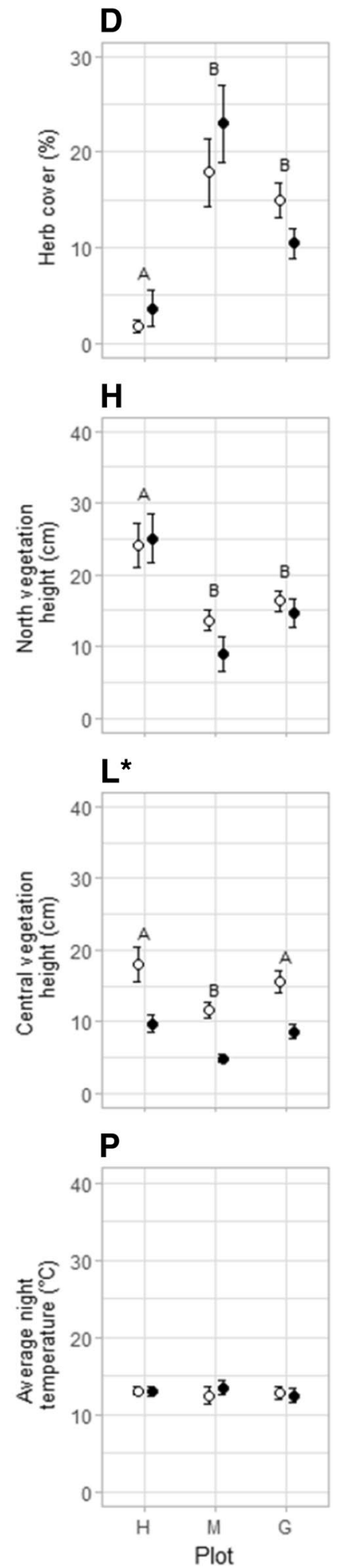

temperature $\left({ }^{\circ} \mathrm{C}\right)$. Means \pm standard error. White circles $=$ unoccupied host plants; Grey filled circles $=$ occupied host plants. Vegetation types: $\mathrm{H}=$ heathland; $\mathrm{M}=$ heath/grassland; $\mathrm{G}=$ Grassland. Asterisk $(*)=$ significant main effect of occupancy. Capital letters above the means indicate significant differences between vegetation types. All vegetation height measurements were back-transformed after square root transformation. Different Y-axis scales are used for each environmental variable 
difference in average daytime temperatures between vegetation types was merely due to different recording dates between vegetation types (Fig. 2o; Table 2). No significant differences were expected nor found for average night-time temperatures (Fig. 2p; Table 2).

\section{Discussion}

\section{Microhabitat conditions}

In this study, larval microhabitat quality for P. malvae was determined on the basis of vegetation and microclimatic variables across a gradient from heathland to acid grassland. So far, microhabitat quality for $P$. malvae had only been determined in calcareous grassland (Brereton 1997; Krämer et al. 2012; Streitberger and Fartmann 2013). VS_HP, as an indicator of food availability, was higher at occupied host plants. However, over the range of habitats, VS_HP was found to be very low in heathland, intermediate in heath/ grassland and very high in grassland. Therefore, contrary to prior knowledge (García-Barros and Fartmann 2009), we surmise that food availability only seems to play a secondary role in determining microhabitat quality by $P$. malvae. Additionally, although not tested, VS_HP variability might also be explained by differences in growth form between the two recorded host plant species. $P$. erecta was only found as host plant in heathland, while $P$. anglica was mainly found in heath/grassland and grassland. $P$. erecta was observed to overcome high dwarf-shrub cover by growing vertically, while $P$. anglica grew strictly as a horizontally spreading, clonal plant. This was further confirmed by the differences in host plant heights between vegetation types, with the highest host plant heights found in heathland. In contrast to VS_HP, VS_G was lower at occupied host plants, especially in heath/ grassland and grassland. This indicates that higher cover of grasses is detrimental for the larval microhabitat quality of P. malvae, as also suggested by Brereton (1997) and Krämer et al. (2012). Cover of mosses and litter was generally higher at occupied host plants, with a high prevalence in the heathland and heath/grassland plots, while being almost absent in the grassland plot. This is also in line with previous findings in calcareous grasslands (Brereton 1997; Krämer et al. 2012), with mosses and litter in heathland performing a similar function as bare ground in calcareous grasslands by generating a warmer above-ground microclimate while at the same time preserving below-ground humidity that may prevent desiccation of the host plant (Krämer et al. 2012). Furthermore, litter might be used as a suitable substrate for pupation and hibernation of $P$. malvae.

In contrast to vegetation cover, vegetation height variables followed a similar pattern across all vegetation types. In all types, the average microhabitat vegetation height was lower in occupied host plants. Shorter vegetation generally induces a warmer microclimate due to the reduction of plant shading which is beneficial for larval development rate (Roy and Thomas 2003; Weiss et al. 1988). This was confirmed by higher daytime temperatures recorded at occupied host plants over all vegetation types. Furthermore, host plant visibility can be improved, a factor known to influence oviposition selection by butterflies (GarcíaBarros and Fartmann 2009). In detail, we found that especially sun-exposed orientations and the central patch at occupied host plants displayed significantly shorter vegetation. This suggests, that even without the potential benefits of (micro)topographical variation on microclimate (see Krämer et al. 2012), P. malvae may benefit from variation in plant canopy structure with lower vegetation in the southern and central parts by an increased exposure of developing caterpillars to solar radiation (also see WallisDeVries 2006).

\section{Influence of wild boar}

WBR was a significant precursor for suitable $P$. malvae larval microhabitats in heath/grassland and grassland plots, by reducing grass encroachment due to shallow rooting (Sandom et al. 2013a) in favour of colonisation by $P$. anglica host plants. Such foraging behaviour is known to alter successional pathways (Sandom et al. 2013a) and underlines the role of the wild boar as an ecosystem engineer in the creation of habitats for other species. Moreover, the impact of WBR shares similarities with sod cutting, a traditional land-use practice that is used in heathland conservation to counter grass encroachment and restore heathland communities (WallisDeVries 2004; Schirmel and Fartmann 2014). Subsequent grazing by red deer, as confirmed from faecal pellet counts (unpubl. data), appeared to contribute in maintaining an open vegetation structure. Therefore, WBR could provide a beneficial complementary disturbance to grazing by either wild ungulates or domestic livestock in the conservation of P. malvae.

This is, to our knowledge, the first study which links wild boar foraging activity to larval microhabitats of a regionally endangered butterfly species. Personal observations by the authors suggest that other butterfly species from early successional microhabitats, such as Erynnis tages, Spialia sertorius and Melitaea cinxia, are also likely to benefit from WBR. However, further research is needed, first, to determine if this beneficial impact indeed extends to other early successional species and, second, to assess the optimum interval in rooting frequency to allow the benefits to outweigh the detrimental effect of habitat destruction (see Carpio et al. 2014) at the short term. 


\section{Conclusion}

In conclusion, our results confirm that $P$. malvae caterpillars occupied warm, open and sparsely vegetated microhabitats in heathland, similar to the findings for calcareous grasslands (Brereton 1997; Krämer et al. 2012; WallisDeVries 2010). Larval microhabitat quality, for three distinct vegetation types in the National Park de Hoge Veluwe, was increased by a higher cover of host plants, mosses and litter at the expense of VS_G. Furthermore, WBR in heath/grassland and grassland proved to be effective in creating suitable larval microhabitats for $P$. malvae by reducing grass dominance due to shallow rooting that favoured $P$. anglica host plants and an open vegetation structure. This suggests that wild boar could have an added value as ecosystem engineers for the preservation of threatened early successional species.

Acknowledgements We want to thank National Park De Hoge Veluwe for permission to carry out this study and supporting scientific research.

Open Access This article is distributed under the terms of the Creative Commons Attribution 4.0 International License (http://creativecommons.org/licenses/by/4.0/), which permits unrestricted use, distribution, and reproduction in any medium, provided you give appropriate credit to the original author(s) and the source, provide a link to the Creative Commons license, and indicate if changes were made.

\section{References}

Bakker J, Berendse F (1999) Constraints in the restoration of ecological diversity in grassland and heathland communities. TREE 14(2):63-68

Barrios-Garcia MN, Ballari SA (2012) Impact of wild boar (Sus scrofa) in its introduced and native range: a review. Biol Invasions 14(11):2283-2300

Bartel RA, Haddad NM, Wright JP (2010) Ecosystem engineers maintain a rare species of butterfly and increase plant diversity. Oikos 119(5):883-890

Bates D, Maechler M, Bolker B, Walker S (2015) Fitting linear mixedeffects models using lme4. J Stat Softw 67(1):1-48

Baubet E, Ropert-Coudert Y, Brandt S (2003) Seasonal and annual variations in earthworm consumption by wild boar (Sus scrofa L.). Wildl Res 30(2):179-186

Boogert NJ, Paterson DM, Laland KN (2006) The implications of niche construction and ecosystem engineering for conservation biology. Bioscience 56(7):570-578

Bos F, Bosveld M, Groenendijk D, Van Swaay CAM, Wynhoff I (2006) De Dagvlinders van Nederland, verspreiding en bescherming (Lepidoptera: Hesperioidea, Papilionoidea). Nederlandse Fauna 7. Nationaal Natuurhistorisch Museum Naturalis, KNNV Uitgeverij European nvertebrate Survey-Netherlands, Leiden

Brereton TM (1997) Ecology and conservation of the butterfly Pyrgus malvae (Grizzled Skipper) in south-east England. University of East London, London

Burrascano S, Copiz R, Del Vico E, Fagiani S, Giarrizzo E, Mei M, Mortellilti A, Sabatini FM, Blasi C (2015) Wild boar rooting intensity determines shifts in understorey composition and functional traits. Community Ecol 16(2):244-253
Byers JE, Cuddington K, Jones CG, Talley TS, Hastings A, Lambrinos JG, Crooks JA, Wilson WG (2006) Using ecosystem engineers to restore ecological systems. TREE 21(9):493-500

Carpio AJ, Castro-López J, Guerrero-Casado J, Ruiz-Aizpurua L, Vicente J, Tortosa FS (2014) Effect of wild ungulate density on invertebrates in a Mediterranean ecosystem. Anim Biodivers Conserv 37(2): $115-125$

Dennis RLH, Shreeve TG, Van Dyck H (2006) Habitats and resources: the need for a resource-based definition to conserve butterflies. Biodivers Conserv 15(6):1943-1966

Enri RS, Probo M, Farruggia A, Lanore L, Blanchetete A, Dumont B (2017) A biodiversity-friendly rotational grazing system enhancing flower-visiting insect assemblages while maintaining animal and grassland productivity. Agric Ecosyst Environ 241:1-10

García-Barros E, Fartmann T (2009) Butterfly oviposition: sites, behaviour and modes. In: Van Dyck H Settele J, Shreeve T, Konvička M (eds) Ecology of butterflies in Europe. Cambridge University Press, Cambridge, pp 29-42

Holmes CW (1974) The massey grass meter dairy farming annual. Massey University, Auckland, pp 26-30

Hothorn T, Bretz F, Westfall P (2008) Simultaneous inference in general parametric models. Biom J 50(3):346-363

Jones CG, Lawton JH, Shachak M (1994) Organisms as ecosystem engineers. Oikos 69(3):373-386

Krämer B, Kämpf I, Enderle J, Poniatowski D, Fartmann T (2012) Microhabitat selection in a grassland butterfly: a trade-off between microclimate and food availability. J Insect Conserv 16(6):857-865

Maes D, Van Dyck H (2001) Butterfly diversity loss in Flanders (north Belgium): Europe's worst case scenario? Biol Conserv 99(3):263-276

Munguira ML, García-Barros E, Martín Cano J (2009) Butterfly herbivory and larval ecology. In: Van Dyck H, Settele J, Shreeve T, Konvička M (eds) Ecology of butterflies in Europe. Cambridge University Press, Cambridge

Poschlod P, Bakker JP, Kahmen S (2005) Changing land use and its impact on biodiversity. Basic Appl Ecol 6(2):93-98

R Core Team (2016) R: a language and environment for statistical computing. R Foundation for Statistical Computing, Vienna

Roy DB, Thomas JA (2003) Seasonal variation in the niche, habitat availability and population fluctuations of a bivoltine thermophilous insect near its range margin. Oecologia 134(3):439-444

Sandom CJ, Hughes J, Macdonald DW (2013a) Rewilding the Scottish Highlands: do wild boar, Sus scrofa, use a suitable foraging strategy to be effective ecosystem engineers? Restor Ecol 21(3):336-343

Sandom CJ, Hughes J, Macdonald DW (2013b) Rooting for rewilding: quantifying wild boar's Sus scrofa rooting rate in the Scottish Highlands. Restor Ecol 21(3):329-335

Schirmel J, Fartmann T (2014) Coastal heathland succession influences butterfly community composition and threatens endangered butterfly species. J Insect Conserv 18(1):111-120

Schultz CB, Russell C, Wynn L (2008) Restoration, reintroduction, and captive propagation for at-risk butterflies: a review of British and American conservation efforts. Isr J Ecol Evol 54(1):41-61

Sims NK, John EA, Stewart AJA (2014) Short-term response and recovery of bluebells (Hyacinthoides non-scripta) after rooting by wild boar (Sus scrofa). Plant Ecol 215(12):1409-1416

Streitberger M, Fartmann T (2013) Molehills as important larval habitats for the grizzled skipper, Pyrgus malvae (Lepidoptera: Hesperiidae), in calcareous grasslands. Eur J Entomol 110(4):643-648

Streitberger M, Fartmann T (2016) Vegetation heterogeneity caused by an ecosystem engineer drives oviposition-site selection of a threatened grassland insect. Arthropod-Plant Interact 10:545-555

Sutherland WJ, Pullin AS, Dolman PM, Knight TM (2004) The need for evidence-based conservation. TREE 19(6):305-308 
Ter Braak CJF, Smilauer P (2002) Canoco for Windows version 4.5. Biometris-Plant Research International, Wageningen

Ter Maat HW, Moors EJ, Hutjes RWA, Holtslag AAM, Dolman AJ (2013) Exploring the impact of land cover and topography on rainfall maxima in the Netherlands. J Hydrometeorol 14(2):524-542

Thomas JA (1991) Rare species conservation: case studies of European butterflies. In: Spellerberg IF, Goldsmith FB, Morris M (eds) The scientific management of temperate communities for conservation. Blackwell Scientific, Oxford, pp 149-197

van Klink R, van der Plas F, van Noordwijk CGE, WallisDeVries MF, Olff H (2015) Effects of large herbivores on grassland arthropod diversity. Biol Rev 90(2):347-366

van Swaay CAM, Cuttlod A, Collins S, Maes D, López Munguira M, Šašić M, Settele J, Verovnik R, Verstrael T, Warren M, Wiemers M, Wynhoff I (2010) European red list of butterflies. Publications Office of the European Union, Luxembourg

Veen P, Jefferson R (eds) (2009) Grasslands in Europe — of high nature value. KNNV Publishing, Utrecht

WallisDeVries MF (1998) Large herbivores as key factors for nature conservation. In: WallisDeVries MF, Van Wieren SE, Bakker JP (eds) Grazing and conservation management. Kluwer, Dordrecht

WallisDeVries MF (2004) A quantitative conservation approach for the endangered butterfly Maculinea alcon. Conserv Biol 18(2):489-499

WallisDeVries MF (2006) Larval habitat quality and its significance for the conservation of Melitaea cinxia in northwestern Europe. Larvalökologie von Tagfaltern und Widderchen in Mitteleuropa Abhandl Westfäl Mus f Naturk Heft 68(3/4):281-294
WallisDeVries MF (2010) Evaluatie van herstelbeheer voor de aardbeivlinder in Zuid-Kennemerland. Report VS2010.033. De Vlinderstichting, Wageningen

WallisDeVries MF, Raemakers I (2001) Does extensive grazing benefit butterflies in coastal dunes? Restor Ecol 9(2):179-188

WallisDeVries MF, van Swaay CAM (2009) Grasslands as habitats for butterflies in Europe. In: Veen P, Jefferson R, De Smidt J, van der Straaten J (eds) Grasslands in Europe. KNNV Publishing, Utrecht, pp 27-34

WallisDeVries MF, Noordijk J, Colijn EO, Smit JT, Veling K (2016) Contrasting responses of insect communities to grazing intensity in lowland heathlands. Agric Ecosyst Environ 234:72-80

Weiss SB, Murphy DD, White RR (1988) Sun, slope, and butterflies: topographic determinants of habitat quality for Euphydryas editha. Ecology 69(5):1486-1496

Welander J (2000) Spatial and temporal dynamics of wild boar (Sus scrofa) rooting in a mosaic landscape. J Zool 252:263-271

Wynhoff I, Grutters M, van Langevelde F (2008) Looking for the ants: selection of oviposition sites by two myrmecophilous butterfly species. Anim Biol 58:371-388

Zollinger R, WallisDeVries MF, Reemer M, Frigge P (2008) Veluwse heide verbonden: Visie op hoe populaties van entomofauna en herpetofauna zijn te verbinden en te versterken binnen het Veluwe Natura 2000 gebied. VOFF-report 2007-2010. Stichting VeldOnderzoek Flora en Fauna, Nijmegen 